\title{
PENGHIMPUNAN DANA ZAKAT DAN FAKTOR PENGHAMBATNYA
}

\author{
Mulfi Aulia ${ }^{1}$
}

\section{Abstrak}

Zakat merupakan bentuk ibadah umat Islam, zakat juga merupakan sumber pemasukan Negara dalam perespektif ekonomi Islam. Di Indonesia lembaga amil zakat resmi sudah berjalan kurang lebih selama dua dekade. Pengumpulan dana zakat dimulai dari gerakan kotak amal hingga menggunakan teknologi digital. Dalam berjibaku di dunia amil zakat, lembaga-lembaga ini sudah menunjukkan perbaikan disetiap tahunnya. Rata-rata pertumbuhan zakat yang dikumpulkan melalui badan amil zakat resmi selama 3 tahun terakhir adalah 23,3\%. Adapun Kenaikan Gross Nasional Produk Indonesia konsisten tumbuh kurang lebih diangka 5\%. Hal ini menunjukkan bahwa tingkat kesadaran orang yang terkena wajib zakat (Muzakki) dalam menyalurkan zaktnya kepada lembaga amil zakat resmi sudah semakin baik. Manajemen Pengelolaan zakat pun demikian, pengumpulan dana zakat sudah sangat beragam sarananya. Namun menurut beberapa pakar penghimpunan dana zakat masih jauh dari potensinya, itupun sudah dikurangi melaui asumsi sejumlah sumber non halal dan jumah muzakki yang ada di Indonesia.

Kata Kunci: Zakat, Gross National Produk, Pengumpulan

\section{Abstract}

Zakat is a form of worship of Muslims, zakat is also a source of state income in the perspective of Islamic economics. In Indonesia the official amil zakat institution has been running for more than two decades. The collection of zakat funds starts from the movement of charity boxes to use digital technology. In struggling in the world of amil zakat, these institutions have shown improvements every year. The average growth of zakat collected through the official amil zakat body over the past 3 years is $23.3 \%$. The National Gross Increase in Indonesian Products has consistently grown at around 5\%. This shows that the level of awareness of the people affected by the obligatory zakat (Muzakki) in distributing zaktnya to the official amil zakat institutions is getting better. Management Management of zakat is also the case, collection of zakat funds has very diverse ingredients. But according to some experts the collection of zakat funds is still far from its potential, and even then it has been reduced through the assumption of a number of non-halal sources and the number of muzakki in Indonesia.

Keywords: Zakat, Gross National Products, Collection

\footnotetext{
${ }^{1}$ Institiut Ilmu Al Qur'an Jakarta, Email: opiaulia7@gmail.com
} 


\section{A. PENDAHULUAN}

Kemiskinan merupakan masalah besar dan sejak lama telah ada, dan hal ini menjadi kenyataan di dalam kehidupan. Islam memandang bahwa masalah kemiskinan adalah masalah tidak terpenuhinya kebutuhan-kebutuhan primer secara menyeluruh. Syariat Islam telah menentukan kebutuhan primer itu (yang menyangkut eksistensi manusia) berupa tiga hal, yaitu sandang, pangan, dan papan. Islam mempunyai perhatian yang tinggi utuk melepaskan orang miskin dan kaum dhuafa dari kemiskinan dan kelatarbelakangan. Islam sangat konsisten dalam mengentas kemiskinan, Islam sungguh memiliki konsep yang sangat matang untuk membangun keteraturan sosial berbasis saling menolong dan gotong royong. Yang kaya harus menyisihkan sebagian kecil hartanya untuk yang miskin dan golongan lainnya. Pemberian tersebut dapat berupa zakat, infaq dan sedekah. Mengeluarkan zakat merupakan kewajiban bagi setiap muslim yang mampu dan telah memenuhi syarat dengan ketentuan syari'at Islam. Bahkan salah satu rukun Islam yang lima. Tidak dapat di pungkiri bahwa zakat sangat berpotensi sebagai sarana yang efektif memberdayakan ekonomi umat. Allah SWT sudah menentukan rezeki bagi tiap-tiap hambanya, sebagian diberikan rezeki yang lebih dibandingkan sebagian yang lain bukan untuk membeda-bedakan. Tetapi kelompok yang diberikan rezeki yang lebih memiliki tanggung jawab untuk membantu kelompok lain yang kekurangan secara Islam melalui zakat, infaq, dan sedekah. Allah SWT dengan tegas menetapkan adanya hak dan kewajiban antar 2 kelompok di atas (kaya dan miskin) dalam pemerataan distribusi harta kekayaan, yaitu dengan mekanisme zakat, sehingga keseimbangan kehidupan sosial manusia itu sendiri akan tercapai serta akan menghapus rasa iri dan dengki yang mungkin timbul dari kelompok yang kurang mampu. Selain itu di dalam harta orang-orang kaya sesungguhnya terdapat hak orang-orang miskin. Zakat bukanlah masalah pribadi yangpelaksanaannya diserahkan hanya atas kesadaran pribadi, zakat merupakan hak dan kewajiban.

Dalam laporaran statistik zakat nasional 2017 yang dipublikasikan pada Juni 2019, Bambang Sudibyo sabagai ketua BAZNAS menyatakan bahwa rata-rata pertumbuhan zakat yang dikumpulkan melalui badan 
amil zakat resmi selama 3 tahun terakhir adalah 23,3\%. Beiau juga mengapresiasi kesadaran masyarakat yang setiap tahun semakin membaik. Yang menarik adalah angka pertumbuhan pengumpulan dana zakat ini tidak terlalu terpengaruh oleh Gross Domestik Bruto, yang artinya memang kinerja amil zakat dan kesadaran masyarakat menyalurkan zakatnya ke lembaga amil zakat resmi membaik.

Melihat dari sebagian besar penduduk Indonesia yang mayoritas menganut agama islam maka sesungguhnya zakat merupakan sektor ekonomi yang memiliki potensi untuk dikembangkan. Meski demikian, upaya untuk menggali potensi dan optimalisasi peran zakat di Indonesia belum sepenuhnya tergarap dengan maksimal karena peran zakat belum terlaksana secara efektif dan efisien.

Banyak faktor yang menyebabkan manfaat dari zakat ini belum terasa maksimal, diantaranya adalah motivasi keagamaan dan kesadaran keislaman pada mayoritas masyarakat masih terus berjalan, diharapkan kesadaran masyarakat dalam menunaikan kewajiban membayar zakat semakin hari semakin membaik. Kurangnya network sharing dan pengawasan dari lembaga-lembaga pengelola zakat juga masih harus diperbaiki, sebagai contoh kecil, kita pasti pernah menemukan dalam sebuah minimarket terdapat beberapa media dari beberapa amil zakat dalam usahanya mengumpulkan zakat. Sehingga dalam pendistribusian zakat masih ada pihak-pihak yang semestinya mendapatkan zakat tidak mendapatkan haknya.

Zakat seyogyanya diberikan kepada delapan golongan, tidak hanya diberikan kepada golongan fakir dan miskin saja, zakat yang diberikan kepada para mustahik sebagian besar digunakan untuk konsumsi sesaat sehingga tidak terjadi kegiatan ekonomi yang bisa mengembangkan harta si mustahik, dan seharusnya zakat yang diberikan oleh muzakki kepada mustahik jangan hanya dalam bentuk uang tetapi juga dalam bentuk modal usaha dan beasiswa pendidikan. Membangun sebuah sistem pengentasan kemiskinan berbasis zakat tentu tidaklah mudah, perlu adanya kerja sama dengan berbagai pihak untuk memaksimumkan peran zakat dalam mengentaskan kemiskinan.

Tugas ini bukan hanya menjadi tanggung jawab pemerintah dan lembaga-lembaga yang mengelola zakat, tapi ini adalah tanggung jawab kita bersama sebagai seorang muslim untuk mensejahterakan muslim lain yang kekurangan. Pembangunan sistem pengelolaan zakat 
yang melibatkan struktur kemasyarakatan yang paling dekat dengan masyarakat itu sendiri harus tetap dikerjakan dan dikembangkan walaupun membutuhkan waktu yang tidak singkat. Upaya mengembangkan potensi zakat memang membutuhkan waktu yang panjang, tetapi masyarakat harus optimis bahwa sistem zakat ini mampu memberikan solusi bagi masalah kemiskinan yang sudah berlarut-larut. Potensi zakat yang sudah ada dan tetap dipertahankan serta kesadaran untuk membayar zakat harus semakin ditingkatkan sehingga peran zakat dalam proses mengentaskan kemiskinan menjadi semakin diakui dan mendapat kepercayaan dari masyarakat luas.

Potensi dan peran zakat yang ada diharapkan menjadi sarana untuk mengentaskan kemiskinan dan mendapatkan perhatian besar, penuntasan penanggulangan kemiskinan harus segera dilakukan dan zakat di harapkan memiliki sumbangsih kepada kaum miskin khususnya yang membutuhkan perhatian dari semua pihak. Seperti usaha yang di lakukan dalam pengembangan potensi zakat melalui upaya Pinjaman Modal Usaha, Pembibitan Ikan, Pembibitan Pertanian, Peternakan, dan Pendayagunaan zakat fakir miskin untuk Pemberdayaan Keluarga Muslim dan pelatihan serta keterampilan agar nantinya masyarakat miskin memiliki bekal berupa pengalaman yang dapat digunakan untuk merubah hidupnya menjadi lebih baik.

\section{B. METODE PENELITIAN}

Dalam tulisan ini, penulis hanya akan mengajukan dua hal yang berhubungan dengan zakat dalam perekonomian. Yang pertama yaitu pola pengukuran potensi zakat dalam manajemen pengelolaan zakat, yang kedua kemudian adalah peran zakat dalam unsur ekonomi Negara dan faktor penghambatnya.

Penelitian ini menggunakan pendekatan kualitatif, yang hasilnya pun akan bersifat deskriptif dengan analisa deduktif, penggambaran akan konsep umum akan dibandingkan dengan realita yang yang ada dalam penelitian ini. Sumber data yangdiperoleh yaitu data tertulis baik berupa riset pustaka dari buku-buku bahasa hingga ekonomi dan media elektronik yang bersumber dari web/domain/situs lembaga amil zakat dan survey. 


\section{ZAKAT SEBAGAI INSTRUMEN PERTUMBUHAN EKONOMI}

Zakat (زكاة) secara bahasa memiliki beberapa makna diantaranya adalah tumbuh (النماء), suci (الطهارة) dan berkembang (الزيادة). Adapun makna zakat secara istilah adalah Zakat dalam syariat islam adalah sebuah istilah yang dengannya diharapkan dapat memberikan nilai tambah pada harta, dapat menyuburkan bahkan mensucikan harta tersebut (Sya'ban, 2018). Hal ini sebagaimana firman Allah dalam Surat atTaubah ayat 103 yang artinya:

"ambillah zakat dari sebagian harta mereka, dengan zakat itu kamu membersihkan dan mensucikan mereka dan mendoalah untuk mereka. Sesungguhnya doa kamu itu (menjadi) ketenteraman jiwa bagi mereka. dan Allah Maha Mendengar lagi Maha Mengetahui."

Imam Ibnu Katsir menyebutkan bahwa harta tersebut (zakat) dapat mensucikan dan membersihkan sipemilik.harta, yang mana sudah menjadi tabiat manusia tidak terlepas dari dosa, seperti mencampur perbuatan baik dengan perbuatan keji (Imam Ibnu Katsir, Tafsir al-Qurani al-'Adhzim, Juz.4: 638). Dalam perniagaan era modern misalnya mencampur kegiatan usaha yang halal dari permodalan yang diragukan kehalalannya bahkan diharamkan. Zakat dapat membersihkan manusia dari kekikiran dan rasa cinta yang berlebihlebihan kepada harta benda. Zakat juga dapat menyuburkan sifat-sifat kebaikan dalam hati mereka dan memperkembangkan harta benda mereka.

Al-Quran menyajikan kata zakat dalam empat gaya bahasa (uslub) yaitu:

1. Uslub Insyai, berupa perintah, seperti dalam surat al-Baqarah ayat 83:

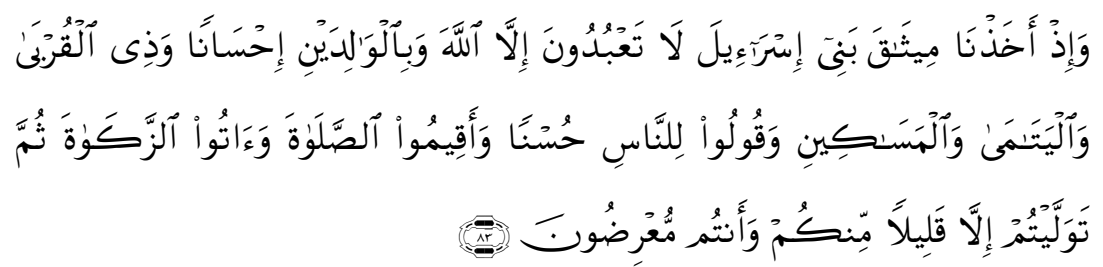

Lafadz "atu" berarti berilah! (perintah untuk mengeluarkan/memberikan). Sasaran dari perintah ini adalah setiap muslim. Selanjutnya dalam surat at-Taubah ayat 103: 


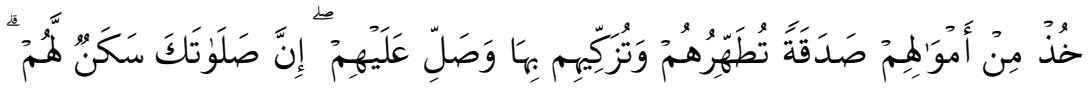

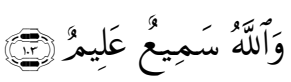

Lafadz "khuz" adalah perintah untuk mengambil zakat/sedekah. Sasaran dari perintah ini adalah penguasa/amil zakat yang akan mengelola zakat tersebut dari para muzakki.

2. Uslub Targhib, yaitu sebuah dorongan atau motivasi membayar zakat, karena merupakan tanda-tanda seseorang yang memilki keimanan dan ketaqwaan secara benar. Hal ini sebagaimana dalam Firman Allah dalam surat al-Baqarah ayat 277:

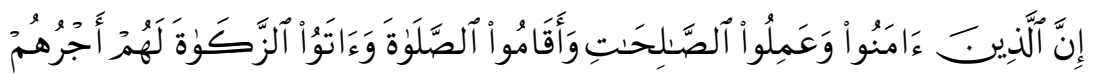

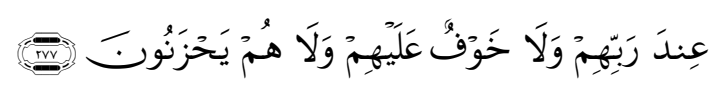

3. Uslub Tarhib, yaitu pernyataan intimidatif atau perintah yang ditujukan pada orang-orang yang menimbun harta kekayaan lagi enggan mengeluarkan hartanya. Orang-orang seperti ini termasuk orang dengan diancam dengan azab yang pedih, sebagaimana dalam surat at-Taubah ayat 34:

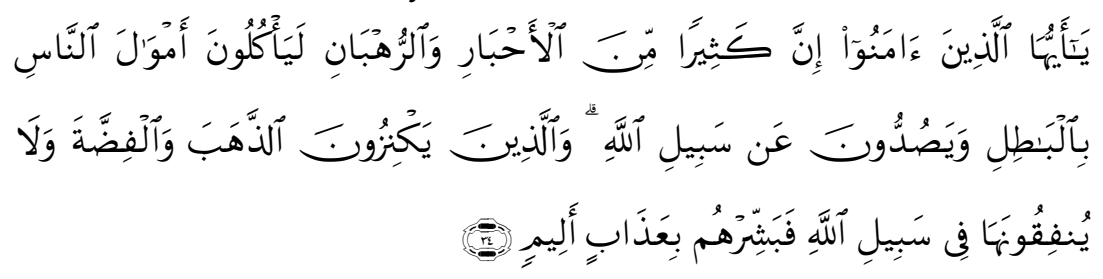

4. Uslub Madh, yaitu gaya bahasa pujian atau sanjungan. Orang-orang yang menunaikan zakat disanjung sebagai wali yang memiliki sifat ketuhanan, kerasulan dan bagian dari orang-orang beriman karena kesanggupan mereka memberikan zakat dari harta yang mereka senangi kepada orang lain. Hal ini sebagaimana firman Allah dalam surat al-Maidah ayat 55: 


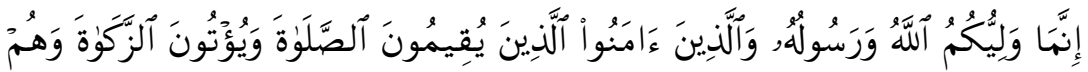 رَكِعُونَ}

Disamping zakat merupakan bentuk ibadah umat Islam, zakat juga merupakan sumber pemasukan Negara dalam perespektif ekonomi Islam. Masih terdapat beberapa sumber pemasukan Negara seperti: usyur (pajak perdagangan), kharaj (pajak pertanian), jizyah (pajak perorangan), khums (pajak harta rampasan perang), warisan orang yang tidak mempunyai ahli waris (kalalah), kaffarat (denda) dan pendapatan lain dari sumber yang halal (Rozalinda, 2016:212).

Zakat pertama kali diwajibkan, telah ditentukan kadar, waktu dan jumlahnya hanya saja masih diperuntukkan bagi fakir dan miskin. Setelah Nabi Muhammad hijrah ke Madinah barulah diberlakukan syarat-syarat yang harus dipenuhi dalam zakat (Marton, 2004: 106). Syarat zakat sendiri terbagi kedalam syarat-syarat yang berhungan dengan muzakki (orang yang mengeluarkan zakat) dan syarat-syarat yang berhungan dengan harta. Adapun syarat yang harus ada pada muzakki yaitu:

1. Merdeka

Maka zakat tidak wajib bagi hamba sahaya atau budak karena hamba sahaya tidak memiliki hak milik. Ulama dari kalangan Malikiyah menambahkan hak milik hamba sahaya tidak bersifat sempurna

2. Islam

Zakat tidak diwajibkan atas orang non-muslim baik kafir maupun murtad, karena ia merupakan ibadah. Menurut Abu Hanifah, riddah (keluar dari agama Islam) menggugurkan kewajiban zakat karena dianggap sama dengan orang kafir (Wahbah Az-Zuhaili, 1989:730). Sedangkan syarat harta yang wajib dikeluarkan zakatnya adalah (Al-Qardhawi, 1994: 171):

1. Dimiliki Secara Sempurna.

Yaitu benar-benar dimiliki oleh orang yang berzakat, maka tidak wajib mengeluarkan zakat dari keuntungan perniagaan yang belum dimiliki atau dikuasai. Harta sempurna kepemilikannya 
dimaksudkan agar muzakki dapat bertindak bebas secara hukum terhadap hartanya, tidak tersangkut didalamnya hak orang lain.

2. Sampai Nishab.

Nishab merupakan batas minimal jumlah harta yang wajib dikeluarkan. Hal ini menunjukkan bahwa zakat merupakan kewajiban bagi orang kaya yang memiliki harta melebihi kebutuhan pokoknya. Dan tidak ada kewajiban mengeluarkan zakat bagi harta yang tidak sampai ambang batas minimal. Dalam fatwa Majelis Ulama Indonesia tentang Zakat Penghasilan, ditetapkan bahwa semua bentuk penghasilan halal wajib dikeluarkan zakatnya dengan syarat telah mencapai nishab dalam satu tahun, yakni senilai emas 85 gram (Fatwa Majelis Ulama Indonesia No.3 Tahun 2003 tentang Zakat Penghasilan).

3. Melebihi Kebutuhan Pokok

Beragamnya kebutuhan pokok manusia, membuat pakar ekonomi Islam menentukan apa-apa saja yang termasuk dalam kebutuhan pokok (primer), sekunder dan tersier agar dapat dijadikan acuan seseorang sudah terkena wajib zakat atau tidak. Dalam surat alBaqarah ayat 219:

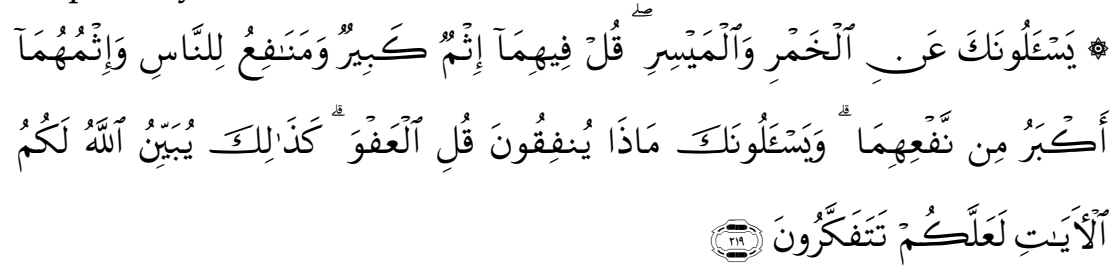

219. mereka bertanya kepadamu tentang khamar[136] dan judi. Katakanlah: "Pada keduanya terdapat dosa yang besar dan beberapa manfaat bagi manusia, tetapi dosa keduanya lebih besar dari manfaatnya". dan mereka bertanya kepadamu apa yang mereka nafkahkan. Katakanlah: " yang lebih dari keperluan." Demikianlah Allah menerangkan ayat-ayat-Nya kepadamu supaya kamu berfikir,

Dalam ayat tersebut, lafaz "العفو" bermakna yang melebihi kebutuhan pokok. Menurut Yusuf al-Qaradhawi kebutuhan pokok yang dimaksud adalah kebutuhan rutin yang harus dipenuhi seseorang dan keluarganya, seperti: makanan, pakaian, tempat 
tinggal dan pendidikan, mulai dari prasarana hingga biaya yang timbul dari proses itu semua.

4. Bebas dari Hutang.

Apabila sipemilik harta mempunyai hutang yang jika dilunasi akan mengurangi nisab hartanya, maka ia tidak wajib wajib zakat. Sebaliknya apabila telah dikurangi hutangnya, namun setalah dihitung sehatun berjalan ia masih memiliki kelebihan harta hingga melewati nishab maka ia wajib zakat.

5. Telah Setahun

Harta yang wajib dizakatkan adalah harta yang kepemilikannya telah mencapai satu tahun. Yaitu untuk harta dari hasil perniagaan, emas, perak dan binatang ternak. Adapun untuk harta dari hasil pertanian adalah waktu panen dengan nishab lima watsaq. Untuk harta rikaz dan barang tambang adalah saat harta itu diperoleh.

6. Dari yang Harta Berkembang/berpotensi dikembangkan.

Harta yang menghasilkan keuntungan/hasil yang diistilahkan dengan harta produktif wajib dizakatkan. Misalkan ternak yang menghasilkan keturunan, rumah/bangunan yang disewakan menghasilkan uang sewa.

Dalam 15 Tausiyah Ekonomi Islam Hendri Tanjung memaparkan bagaimana zakat memiliki kelebihan secara ekonomi dibandingkan dengan bentuk pemberian yang bersifat sukarela seperti sedekah. Menurutnya, sedekah sangat tergantung dengan niat baik dari pemberi sedekah yang mana tidak ada aturan waktunya dan besarnya jumlah pemberian tersebut (Tanjung, 2016: 97). Disisi lain, sedekah juga tidak permanen, tidak teratur, sehingga tidak dapat divalidasi secara laporan maupun aktual dalam infrastruktur ekonomi kenegaraan saat ini.

Dalam bukunya Nurul Huda memaparkan zakat juga mempunyai aturan yang jelas dan adil, karena itu dalam sistim zakat diwajibkan bagi setiap orang untuk membayarkan 2,5\% dari harta yang dimiliki setiap tahunnya. Hal ini akan memberikan dorongan kepada para penerima zakat agar dapat memberdayakan uang atau harta yang mereka terima dengan baik sehingga peningkatan ekonomi yang diharapkan dapat tercapai (Huda, 2015: 133). Dengan adanya zakat dari harta yang tertimbun ini dapat mengakibatkan pengaruh yang sangat signifikan terhadap beberapa sector ekonomi, seperti daya produksi 
meningkat, mengurangi pengangguran, pengurangan perbedaan pendapatan. Pada kenyataannya zakat tidak akan habis dikonsumsi akan tetapi hasil penerimaannya benar-benar disalurkan dan diberdayakan melalui kegiatan-kegiatan ekonomi dan selanjutnya dapat menghasilkan keuntungan.

Gambar 1 Skema Peran Zakat dalam Pergerakan Ekonomi Negara

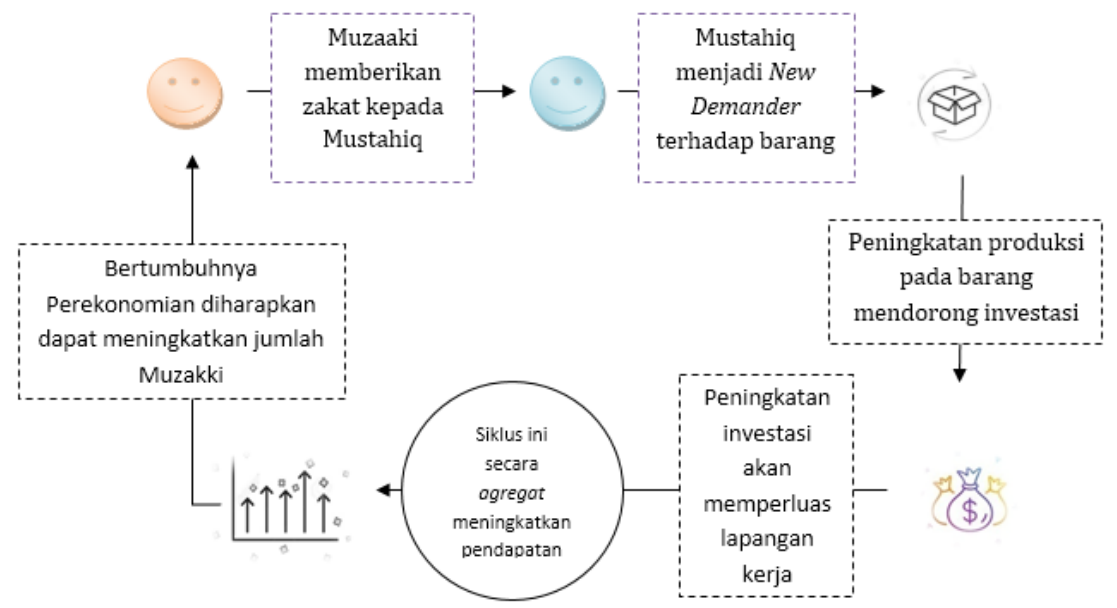

Tujuan dari disyariatkannya zakatpun amat erat kaitannya dengan dampak aplikasi zakat pada perekonomian Negara. Diantara dampak yang tampak langsung dari masyarakat yaitu:

- Produksi

Zakat dapat memunculkan new demander sehingga akan meningkatkan permintaan secara agregat, yang berujung pada terdorongnya produsen untuk meningkatkan produksi guna memenuhi permintaan baru.

- Investasi

Dampak lain yang muncul dari peningkatan produksi yaitu akan mendorong perusahaan (produsen) untuk meningkatkan energinya khususnya dalam bidang permodalan.

- Lapangan Kerja

Karena adanya peningkatan investasi, maka terdoronglah tingkat produksi yang lebih tinggi lagi yang pada akhirnya akan membuka kesempatan kerja yang lebih besar.

- Pertumbuhan Ekonomi 
Peningkatan konsumsi secara agregat dan peningkatan investasi yang sejalan meningkatkan laju pertumbuhan ekonomi secara makro.

- Kesenjangan Sosial

Zakat memiliki peran dalam mendistribusikan pendapatan khususnya dalam mengurangi kesenjangan (gap) pendapatan yang pada akhirnya akan mengurangi kesenjangan sosial (Huda et al., 2008: 18).

Dari paparan diatas kita mendapatkan gagasan bahwasannya kunci untama dari sistim zakat terdapat pada pengelolaannya, diharapkan dengan bertambahnya jumlah muzakki, berkuranglah apa yang menjadi salah satu permasalahan dalam ekonomi yaitu kemiskinan. Maka pengelolaan zakat yang tepat dan konsisten dapat mempercepat pertumbuhan ekonomi suatu Negara, terlebih lagi Negara yang mayoritas penduduknya adalah Muslim.

\section{Pola Pengukuran Potensi zakat dalam Manajemen Pengelolaan Zakat}

Yang termasuk dalam lingkup manajemen pengelolaan zakat yaitu: manajemen data, berkas, informasi, manajemen jaringan, manajemen lini, manajemen personalia, manajemen risiko dan lainlain. Dalam Kamus Besar Bahasa Indonesia, pengelolaan berarti : proses, cara, perbuatan mengelola / melakukan kegiatan tertentu dengan menggerakkan tenaga orang lain / proses yang membantu merumuskan tujuan organisasi / proses yang memberikan pengawasan pada semua halyang terlibat dalam pelaksanaan dan pencapaian tujuan (Kamus Besar Bahasa Indonesia V).

Salah satu karakteristik Ekonomi Islam adalah al-Raqabah alMazdujah yang artinya bahwa dalam ekonomi Islam salah satu unsurnya yang melekat adalah pengawasan pada setiap manusia didalamnya (Hulwati, 2006: 3). Pengawasan mulai dari diri masingmasing, karena manusia merupakan pemimpin dirinya sendiri dan akan dimintai pertanggung jawabannya kelak pada Hari Perhitungan. Yang kedua pengawasan dari luar diri. Institusi, lembaga ataupun pengawas eksternal lainnya juga ikut terlibat dan bertanggung jawab atas pengelolaan sumber daya ekonomi Islam. Adanya bait al-mal \& bait al-tamwil dalam sejarah umat islam merupakan bukti berlangsungnya karakteristik ini. 
Pengelolaan zakat melalui amil zakat resmi di Indonesia telah berjalan kurang lebih selama dua dekade. Pada tahun 2005 Di beberapa lembaga amil zakat, seperti BAZIS DKI, dapat kita lihat beberapa kebijakan yang telah dilakukan dalam pendayagunaan zakat. Lembaga amil ini telah melakukan kebijakan dengan mempertimbangkan keadaan sosial mustahik. Ada tiga sasaran pendayagunaan zakat, yaitu: pertama, fakir miskin dalam bentuk produktif (bantuan modal kerja, beasiswa dan layanan kesehatan) dan konsumtif (75\%). Kedua, sabilillah dalam bentuk bantuan sarana, prasarana dan pembinaan kegiatan keislaman (22\%). Ketiga, muallaf, gharimin dan ibnu sabil sebesar 1\% (Bamualim \& Bakar, 2005:44).

Beberapa Model pengukuran potensi zakat dapat digunakan sebagai alat pelaporan, berikut penulis sajikan model pengukuran potensi zakat. Potensi zakat adalah kemampuan zakat dalam upaya pemanfaatan zakat untuk digunakan dan dimanfaatkan secara optimal. Potensi zakat apabila digunakan dengan pemanfaatan dan mekanisme yang tepattentu dapat digunakan untuk mengentaskan kemiskinan dikalangan umat muslim. Potensi zakat dimasing-masing daerah akan berbeda sesuai dengan struktur dan tingkat kemajuan suatu daerah tersebut. Semakin maju suatu daerah maka akan semakin besar potensi zakat yang dapat digali. Untuk mengetahui besar potensi zakat digunakan metode perkiraan potensi zakat yang digunakanberdasarkan asumsi dimana kadar zakat minimal 2,5\% hingga $5 \%$ dari masing-masing sektor ekonomi seperti berikut :

1. Kadar zakat pertanian adalah $5 \%$ dari nilai PDB sektor pertanian

2. Kadar zakat pertambangan adalah 2,5\% dari nilai PDB sektor pertambangan

3. Kadar zakat sektor lainnya adalah masing-masing 2,5\%.

Ataupun dengan cara menyamakan kadar zakat sebesar 2,5\% dan membandingkan dengan rata-rata jumlah Pendapatan Domestik Bruto dan Produk Nasional Bruto.

Dalam Statistik Zakat Nasional, penghimpunan dana zis berhasil dikumpulkan oleh badan amil resmi Negara tahun 2017, mencapai angka 6,224 Milyar Rupiah, sedangkan pada tahun sebelumnya mencapai 5,017 Milyar Rupiah, kenaikan pengumpulan dana ini sebesar 1,2 Triliun atau setara dengan 24\%. Perekonomian Indonesia tahun 2017 yang diukur berdasarkan Produk Domestik Bruto (PDB) 
atas dasar harga berlaku mencapai Rp13.588 triliun (BPS, 208). Sedangakan pada tahun 2016 PDB diatas mencapai Rp.12,406 triliun. Selisih sebesar Rp.1,152 triliun ini Apabila dibandingkan dengan PDB perkapita dan diukur dengan kurs Dollar maka PDB tersebut tumbuh sebanyak $5,1 \%$.

Dari angka diatas kita akan berpendapat bahwa sangatlah jauh jauh pengumpulan zakat apabila dibandingkan dengan GDP. Oleh karena asumsi selanjutnya adalah dengan memporsikan jumlah muzakki yang ada di Indonesia. Biasanya para pakar akan membuat range mulai dari 15 s.d 20\% jumlah muzakki yang ada di Indonesia.

Dalam bukunya yang berjudul Ekonomi Islam Rozalinda menggagas bahwasannya manajemen zakat juga dapat dioptimalkan dalam 4 hal:

1. Optimalisasi Fungsi Masjid.

Zakat sebagai salah satu pilarnya diyakini menjadi salah satu inti penggerak pemberdayaan ekonomi masyarakat miskin. Masjid dapat difungsikan kembali sebagai pusat kegiatan masyarakat untuk mewujudkan masyarakat muslim yang cerdas, sehat, mandiri dengan program dan bertaqwa. Pemberdayaan ekonomi masyarkat berbasiskan masjid dirasa perlu, mengingat masjid adalah tempat yang selalu ada disetiap pelosok Indonesia, tempat yang paling dekat dengan komunitas Muslim. Kader masjid diharapkan mampu mendata muzakki dan mustahiq serta memprogram pelaksanaan zakat mal terpadu.

2. Masjid to Masjid Network Manajemen.

Masjid dapat melakukan koordinasi antar masjid mengenai daerah arsiran potensi muzakki dan mustahiq. Mengingat adanya beberapa masjid dalam satu daerah, maka koordinasi ini dapat efektif dengan menunjuk satu masjid masjid induk sebagai koordinator sistim, pengelolaan dan pencatatan.

3. Kerja Sama BAZ/LAZ dengan Masjid.

Lembaga amil zakat dapat melakukan kerjasama dengan institusi masjid karena wilayah kerja BAZ biasanya terbatas. Kalaulah BAZ melakukan kerjasama dengan masjid dalam pengelolaan zakat, tentulah akan banyak zakat terhimpun.

4. Optimalisasi sistim distribusi.

Bentuk inovasi distribusi dikategorikan dalam empat bentuk; pertama, distribusi bersifat konsumtif tradisional, yaitu zakat 
diberikan untuk dimanfaatkan secara langsung agar memenuhi kebutuhan sehari-hari. Kedua, distribusi bersifat konsumtif kreatif, yaitu zakat diberikan dalam bentuk peralatan belajar. Ketiga, distribusi bersifat produktif yang bias menciptakan lapangan kerja bagi fakir miskin seperti hewan ternak. Keempat, distribusi dalam bentuk produktif kreatif, yaitu zakat dalam bentuk modal kerja bagi pedagang atau usaha kecil (Rozalinda, 2016:268). Golongan penerima zakat atau mustahik dapat digeneralkan menjadi 2 golongan, yaitu: pertama, kelompok permanen yaitu golongan yang diasumsikan selalu ada dalam jangka waktu yang panjang, seperti fakir, miskin, dan 'amilin. Dalam penyaluran zakat, kelompok ini adalah golongan yang mendapat prioritas utama dari delapan (8) golongan lainnya, sebagaimana dalam surat at-Taubah ayat 60 :

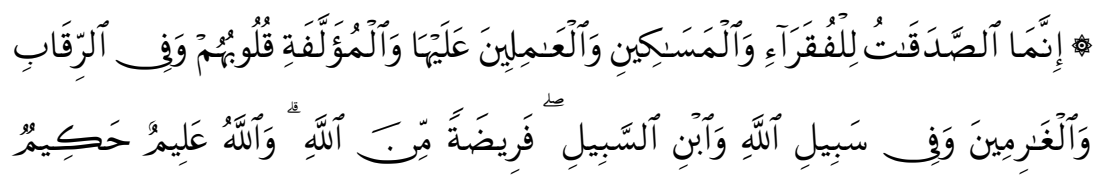

"Sesungguhnya zakat-zakat itu, hanyalah untuk orang-orang fakir, orang-orang miskin, pengurus-pengurus zakat, Para mu'allaf yang dibujuk hatinya, untuk (memerdekakan) budak, orang-orang yang berhutang, untuk jalan Allah dan untuk mereka yuang sedang dalam perjalanan, sebagai suatu ketetapan yang diwajibkan Allah, dan Allah Maha mengetahui lagi Maha Bijaksana".

Pengelolaan zakat merupakan wilayah eksplorasi yang disediakan oleh Islam bagi manusia. Secara sempurna, Islam telah menyediakan bingkai aturan yang tidak boleh dilanggar dan mendorong manusia melakukan inovasi di dalam bingkai tersebut untuk mewujudkan esensi zakat. Fokusnya adalah menemukan titik temu dari aturan yang bersifat kaku dan mutlak dengan kehidupan manusia yang sangat dinamis. Sejarah membuktikan bahwa hal tersebut dapat dilakukan dan menghasilkan keluaran yang sangat baik.

Dinamika pengelolaan zakat terletak pada proses dialektikanya. Proses ini merupakan upaya menemukan esensi zakat serta ruh 
aturannya untuk kemudian diterjemahkan dan diaplikasikan pada kondisi yang jauh berbeda dibandingkan dengan masa-masa awal berdirinya Islam dan Zakat. Ini menyebabkan apa yang saat ini secara teknis dianggap benar akan bergandengan dan digantikan dengan teknis/metoda yang lebih benar. Karena itu pengelolanya memerlukan ketaatan tinggi pada aturan syariah sekaligus memiliki wawasan yang luas dan dinamis dalam menemukan peluang memperkuat proses pengelolaan zakat (Rahman, 1996).

Beberapa keuntungan apabila zakat dikelola oleh lembaga khusus adalah:

1. Meningkatkan kedisiplinan dalam pembayaran zakat.

2. Menjaga perasaan mustahiq apabila menerima langsung dana zakatnya dari muzakki.

3. Agar alokasi yang dilakukan tepat sasaran dan dengan tepat didistribusikan menurut skala prioritas yang benar.

4. Memperlihatkan syiar Islam dalam semangat penyelenggaraan pemerintahan islami. Sebaliknya, jika zakat diserahkan langsung dari muzzaki pada mustahiq, meskipun secara hukum syariah sah, akan tetapi disamping akan terabaikannya hal-hal tersebut diatas hikmah dan fungsi zakat, terutama yang berkaitan dengan kesejahterraan umat, akan sulit diwujudkan.

Di Indonesia terdapat 6 (enam) lembaga amil zakat yang telah terdaftar dalam Lembaga Amil Zakat Indonesia, yaitu (Zakat.or.id):

1. Dompet Dhuafa Republika

2. Badan Amil Zakat Nasional (BAZNAS)

3. Inisiatif Zakat Indonesia

4. Yatim Mandiri Surabaya

5. NU Care LAZIS NU (Lembaga Amil Zakat Infaq dan Shadaqah Nahdhatul Ulama)

6. LAZIS MU (Lembaga Amil ZAkat Muhammadiyah)

Ditambah lagi terdapat 16 (enam belas) lembaga amil zakat yang sudah mendapatkan izin dari Kementerian Agama baik itu pada tingkat Nasional maupun Provinsi. Penulis asumsikan masih banyak lagi amil zakat yang sudah berjalan namun memang belum terdaftar di Kementerian Agama. 
Seiring dengan kemajuan konsep dan teknologi, lembaga amil zakat di Indonesia telah mengadopsi dan menggunakan layanan internet/online/daring untuk memudahkan pengumpulan zakat, infaq dan sedekah. Selain memudahkan amil zakat mengumpulkan zakat, teknologi tersebut juga mengoptimalkan pelaporan zakat dalam skala nasional. BAZNAS selaku lembaga amil zakat juga lembaga yang ditunjuk oleh pemerintah untuk membuat statistik dan pelaporan zakat dalam skala nasional.

Teknologi ini muncul sebagai alternatif bagi masyarakat yang ingin menunaikan zakat ataupun memberikan donasi. Dalam laporan statistik zakat nasional per 2017, Ketua BAZNAS, Prof. Bambang Sudibyo dan Deputi BAZNAS, Arifin Purwakananta menyampaikan bahwa potensi zakat di Indonesia mencapai sekitar 217 triliun walau dalam pengelolaannya baru 2,9\% nya atau 6 triliun per tahun (Baznas, 2018: 3-4). Dengan adanya tren zakat secara daring diharapkan dapat memaksimalkan potensi tersebut dengan cara pembayaran yang mudah, cepat dan praktis.

Zakat online sendiri merupakan proses pembayaran zakat yang dilakukan melalui sistem digital, di mana saat melakukan pembayaran zakat, muzaki (orang yang menunaikan zakat) tidak langsung bertemu dengan amil zakat. Sistem zakat online ini merupakan bentuk adaptasi bagi para wajib zakat dalam rangka perkembangan zaman, di mana dengan bantuan teknologi masyarakat mendapatkan berbagai kemudahan dan dapat meraih pangsa pasar yang lebih luas.

Pelayanan dalam pembayaran zakat pun dapat dilakukan dengan beberapa metode, antara lain menggunakan internet banking, virtual account, e-money, dan juga melalui platform e-commerce. Sejumlah platfrom e-commerce di Indonesia telah bekerja sama dengan pengelola zakat untuk menyediakan fitur pembayaran zakat online. Namun, pembayaran zakat melalui sistem online ini memunculkan respon yang berbeda dikalangan masyarakat. Hukum tentang boleh tidaknya menunaikan zakat melalui online masih menjadi hal yang diperdebatkan. Pada dasarnya ijab qabul bukanlah salah satu dari rukun zakat dan juga syarat sah zakat, hal ini berbeda dengan jual beli, wakaf, gadai dan sebagainya.

Syaikh Yusuf Al-Qaradhawi dalam fiqhuzzakat-nya berpendapat bahwa seorang muzakki dapat melafadzkan niatnya dan kadar 
zakatnya begitupun dengan mustahik selama itu dipandang mudah (Al-Qardhawi, 1994). Dalam layanan daring seorang muzakki hanya perlu menggunakan jarinya untuk menunaikan zakat. Oleh karenanya, muzakki dapat menyerahkan zakatnya secara online kepada lembaga amil zakat tanpa menyatakan kepada mustahik bahwa uang yang ia serahkan adalah zakat.

Menurut survey yang dilakukan penghimpun donasi Rumah Zakat, pergeseran tren dalam hal pembayaran zakat telah terjadi sejak tahun 2015, di mana masyarakat lebih memilih menunaikan zakatnya secara online dibandingankan dengan cara konvensional. Pada tahun 2016, Rumah Zakat berhasil memperoleh 75 persen dari Rp230 miliar dana zakat yang diperoleh dengan pembayaran via online. Selaras dengan hal tersebut, Direktur Utama Baznas Arifin Purwakananta mengatakan, pembayaran zakat saat ini telah terjadi pergeseran dari cara yang bersifat konvensional menjadi online, ini menunjukkan kecenderungan perilaku konsumen saat ini.

Pada tahun 2016, masyarakat yang membayar zakat secara online hanya 1 persen, tetapi di tahun 2017 pertumbuhannya meningkat hingga 12 persen. Sementara pada tahun 2020 pihaknya memprediksi masyarakat yang menunaikan zakat secara online tumbuh hingga 50 persen mengingat perkembangan digital saat ini sangatlah signifikan.

Di Indonesia sendiri, terdapat beberapa platform penyedia layanan membayar zakat melalui sistem online, salah satunya adalah Kitabisa.com. Co-Founder dan CEO Kitabisa.com, M. Alfatih Timur mengatakan fitur zakat online di situs Kitabisa.com telah ada sejak tahun 2016, jenis zakat yang dapat dibayarkan secara online melalui platform Kitabisa.com adalah zakat profesi dan zakat maal.

Menurutnya, perkembangan zakat online di situs Kitabisa.com cukup baik, data pada kuartal pertama yaitu januari hingga april 2017 jumlah zakat yang terkumpul Rp1.413.644.854. pada periode yang sama di tahun 2018 naik menjadi Rp2.615.215.209. Sementara itu, jumlah muzaki pada periode tersebut meningkat dari 3.640 orang menjadi 6.540 orang. Jika ditotal dari januari 2016 hingga aplil 2018, jumlahnya mencapai 16.292 orang (Kitabisa.com).

Beberapa situs lembaga pengelola zakat di Indonesia juga telah memberikan opsi untuk melakukan zakat secara online sehinga dapat memudahkan masyarakat dalam membayar zakat, diantaranya adalah Dompet Dhuafa, yang menyediakan situs zakat.or.id bagi masyarakat 
yang ingin memberikan donasi atau zakat secara online, pembayaran disediakan dalam beberapa metode mulai dari transfer bank hingga potong pulsa ponsel.

Rumah Zakat, dalam situs Rumah Zakat terdapat opsi pembayara via online, di mana disediakan fitur kalkulator zakat untuk memudahkan dalam membayar zakat, selanjutnya akan diberikan konfirmasi atas besaran jumlah zakat yang diberikan dengan mengisi informasi di situs tersebut.

Badan Amil Zakal Nasional, dukungan layanan online yang dimiliki Baznas cukup beragam dengan opsi pembayaran yang beragam, Baznas juga meluncurkan aplikasi berbasis android untuk memudahkan masyarakan membayar zakat. Meskipun terlihat mudah dan praktis, hendaknya kita juga perlu waspada ketika berniat menyalurkan zakat melalui platform online, setidaknya ada lima hal yang perlu diperhatikan saat ingin menyalurkan zakat secara online, yaitu:

1. Kenali lembaga amil zakat, pastikan lembaga amil zakat tersebut terdaftar di BAZNAS dan mempunyai izin dari Kementerian Agama.

2. Keaslian mobile app, kita dapat membaca ulasan-ulasan tentang aplikasi tersebut dari para pengguna sebelumnya, sehingga kita dapat mengambil kesimpulan apakah app tersebut cukup terpercaya untuk menyalurkan zakat secara online.

3. Cek track record penyedia layanan zakat online, caranya kita dapat melakukan riset kecil di internet dengan mencari berita berkaitan dengan penyedia layanan zakat online yang ingin kita gunakan.

4. Tidak menggunakan rekening pribadi, rekening yang mengatasnakaman lembaga/institusi akan lebih terpercaya daripada rekening atasnama pribadi.

5. Meminta bukti penyaluran zakat.

\section{Peran Zakat Terhadap Distribusi Kesejahteraan dan Faktor Penghambatnya.}

Sejarah umat Islam secara jelas menggambarkan hubungan yang saling mempengaruhi antara rakyat (C), syariah sebagai sistem(S), pemerintah (G), kesejahteraan/ekenomi (W), keadilan dan pembangunan (J) dalam hal kemajuan atau kemunduran suatu 
masyarakat dan peradaban (Huda, 2008). Hubungan yang berkaitan ini dapat diaplikasikan pula dalam ekonomi, Mari kita perhatikan seluruh variabel ini pada skema berikut:

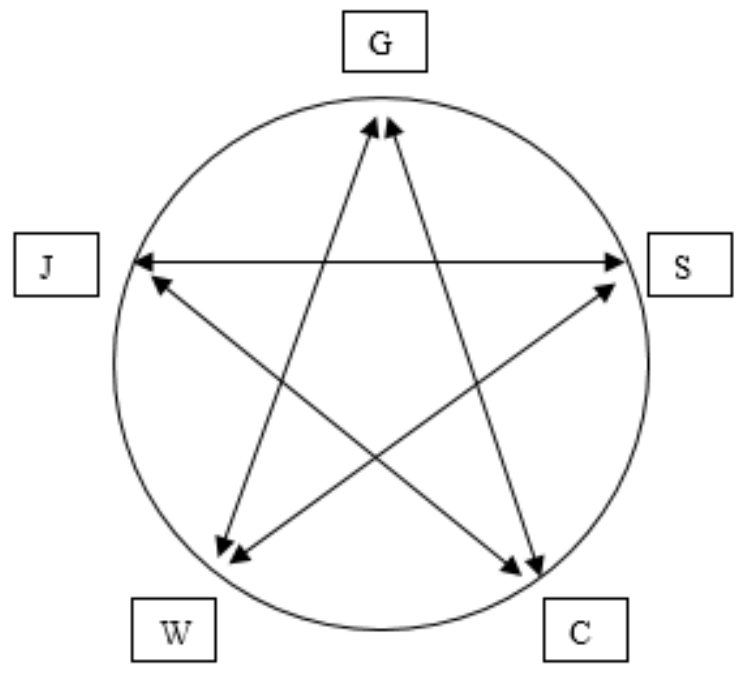

Otoritas dari pemerintahan $(\mathrm{G})$ dijadikan sebagai starting up dari suatu Negara untuk menjalankan seluruh aspek berbangsa dan bernegara, dimana yang terkena dampak langsung dari otorisasi ini adalah rakyat suatu negeri (C). Hubungan antara keduanya sangat dipengaruhi oleh garis singgung nilai-nilai syariah (S) atau ideologi yang berlaku pada suatu Negara (P3EI, 2015:13). Maka untuk skema dalam Negara Indonesia, syariah (S) dapat kita asumsikan menjadi Pancasila. Kemudian, rasa keadilan dan pembangunan (J), baik infrastruktur dan sumberdaya manusia akan dapat tercipta baik setelah adanya hubungan baik antara pemerintah dan rakyat yang dibangun dengan asas kepercayaan dan ideologi yang dianut bersama. Yang menjadi penentu rasa keadilan dan pembangunan yaitu adanya kesejahteraan merata dan seimbang (W), baik itu yang menyangkut pada hak dan kepemilikan setiap individu suatu Negara. Rasa keadilan yang tercipta dan kemajuan pembangunan yang sustainable dengan sendirinya akan menyebabkan terpeliharanya ideology suatu Negara (S). Garis singgungnya adalah otoritas pemerintah. Apabila kebijakan baru yang dibuat akibat bergeraknya peradaban merupakan kebijakan yang tepat, maka ideologi ini pun akan semakin kuat hingga mampu 
mengawal tambahan kekayaan (W) dari hasil kegiatan ekonomi suatu Negara. Perilaku ekonomi dari rakyat merupakan faktor terpenting untuk menambah kekayaan suatu Negara.

Dari bertambahnya kesejahteraan dan kekayaan suatu Negara yang langsung merasakan prestasi tersebut secara langsung adalah Pemerintah $(G)$. yang perlu diingat adalah faktor penentu prestasi pemerintah ini adalah rasa keadilan yang tercipta dimasyarakat dan pembangunan, baik itu pembangunan sumberdaya manusia maupun infrastrukurnya.

Zakat memiliki peranan dalam distribusi kesejahteraan. Dalam hal mekanisme distribusi pendapatan misalnya, zakat memiliki peran ganda untuk meningkatkan keadilan distribusi:

1. Zakat berfungsi mengurangi tingkat pendapatan yang siap dikonsumsi oleh segmen wajib zakat (orang-orang kaya). Oleh karena itu pengimplementasian zakat diharapkan akan mampu menahan tingkat konsumsi segmen wajib zakat sehingga kurva permintaan segmen wajib zakat tidak meningkat drastis. Positifnya adalah harga komoditas yang dikonsumsi masyarakat menengah dan atas tidak mengalami kenaikan.

2. Zakat berfungsi sebagai media transfer pendapatan (P3EI, 2015: 405), sehingga mampu meningkatkan daya beli mustahik. Dengan ini diharapkan mustahik dapat terpenuhi kebutuhannya dan komoditas yang menjadi kebutuhan dasar manusia meningkat produksinya.

Dalam skema sistim bunga, yang pasti diuntungkan dan selalu diuntungkan adalah pemilik dana dengan transaksi qardnya, hal ini sebagaimana yang dianut dalam mazhab ekonomi kapitalis. Terlebih lagi perusahaan perusahaan dalam bentuk lembaga keuangan konvensional menjadi ikon-ikon perusahaan dengan keuntungan terbesar di Negara kita ini. Beberapa perusahan merilis kinerja keuangan pada laba berjalan semester I-2019 sebagaimana yang terdapat pada tabel i. kinerja laba emiten yang terdaftar di index LQ45 (cnbcindonesia.com). 
Tabel 1. Kinerja Laba Emiten yang Terdaftar di Indeks LQ45

\begin{tabular}{|l|r|r|}
\hline \multicolumn{1}{|c|}{ Perusahaan } & Laba (Miliar Rp) & \multicolumn{2}{c|}{ Laba (\% YoY) } \\
\hline Bank BRI/BBRI & 16.300 & 12.01 \\
\hline Bank Mandiri/BMRI & 13.531 & 11.11 \\
\hline Bank BCA/BBCA & 12.862 & 12.61 \\
\hline Telkom/TLKM & 11.078 & 27.36 \\
\hline Astra International/ASII & 9.803 & -5.60 \\
\hline Bank BNI/BBNI & 7.634 & 2.66 \\
\hline HM Sampoerna/HMSP & 6.770 & 10.75 \\
\hline
\end{tabular}

Dengan laporan laba seperti ini, orang akan lebih tertarik menginvestasikan uangnya/hartanya pada emiten konvensional.

Disisi lain yang dapat kita syukuri hingga saat ini adalah dengan tidak adanya regulasi mutlak dari pemerintah terhadap penghimpunan dan penyaluran zakat, maka angka potensi zakat di Indonesia pada prinsipnya adalah asumsi, Masih banyak para muzakki yang melakukan pendistribusian zakat secara mandiri (person to person). Oleh karenanya kajian atau edukasi seputar zakat kepada khalayak umum tetap menjadi layak untuk ditelaah.

\section{PENUTUP}

Disamping zakat memiliki peranan dalam kesejahteraan, menurut penulis zakat juga memiliki beberapa faktor penghambat dalam skema makro ekonomi. Produktivitas zakat akan terganggu dengan pola perekonomian yang buruk seperti: ketidaktahuan umat muslim dengan kewajibannya, eksklusifitas suatu mazhab fiqih yang dianut dalam pengelolaan zakat, transaksi yang diharamkan syariat, pengelolaan harta yang buruk, dan budaya malas bangsa. Faktor yang menjadi penghambat selanjutnya adalah sistim bunga yang dianut oleh suatu Negara dan beberapa Negara lainnya yang menggunakan jasa pinjaman dari lembaga moneter internasional. Yang kemudian diteruskan sistimnya oleh lembaga-lembaga keuangan konvensional dalam negeri dan masyarakat lainnya.

\section{DAFTAR PUSTAKA}

Al-Qaradhawi, Y. (1994). Figh az-Zakah, Dirasah Muqoronah li Ahkamiha wa Falsafatiha fi Dhau'I Al-Quran wa Sunnah. Kairo: Maktabah Wahbah. 
Az-Zuhaili, W. (1989). al-Figh al-Islami wa Adillatuhu. Beirut: Dar al-Fikr.

Badan Amil Zakat Nasional. (2018). Statistik Zakat Nasional 2017. Jakarta: Bagian Liaison dan Pelaporan).

Bamualim, C. S. \& Bakar I. A. (2005). Revitalisasi Filantropi Islam: Studi Kasus Lembaga Zakat dan Wakaf di Indonesia. Jakarta: Center for Languages and Culture.

Fatwa Majelis Ulama Indonesia No.3 Tahun 2003, tentang Zakat Penghasilan

Huda, N. (2015). Ekonomi Pembangunan Islam. Jakarta: Adhitya Andrebina Agung.

Huda, N. et al. (2008). Ekonomi Makro Islam Pendekatan Teoritis. Jakarta: Kencana.

Hulwati. 2006. Ekonomi Islam. Jakarta: Ciputat Press Group.

Imam Ibnu Katsir. (1431 H). Tafsir al-Qurani al-'Adhzim, ditahqiq oleh Hikmat bin Basyri bin Yasin, Juz.4, Al-Mamlakah al-Arabiyah as-Saudiyah: Dar Ibnu al-Jauziy.

Kementerian Pendidikan dan Kebudayaan Republik Indonesia. Kamus Besar Bahasa Indonesia V. (Aplikasi Luring Resmi Badan Pengembangan Bahasa dan Perbukuan).

Marton, S. S. (2004). Ekonomi Islam: Di tengahKrisis Ekonomi Global. Jakarta: Zikrul Hakim.

Pusat Pengkajian dan Pengembangan Ekonomi Islam (P3EI). (2015). Ekonomi Islam. Jakarta: RajaGrafindo Persada.

Rahman, A. (1996). Doktrin Ekonomi Islam. Yogyakarta: Dana Bhakti Wakaf.

Rozalinda. (2016). Ekonomi Islam: Teori dan Aplikasinya Pada Aktivitas Ekonomi. Depok: RajaGrafindo Persada.

Sya'ban, Muhammad Toha tentang Pengertian Zakat secara bahasa $\mathcal{E}$ istilah, Syabkah Alukah diakses pada tanggal 27 Juni 2018.

Tanjung, H. 2016. 15 Tausiyah Ekonomi Islam. Bogor: UIK Press.

https://zakat.or.id/daftar-lembaga-amil-zakat/ diakses pada 25 Januari 2020

https://kitabisa.com/about-us diakses pada tanggal 25 Januari 2020 